\title{
Knowledge of the characteristics and properties of wine before consumers
}

\author{
E.J. Dezengrini
}

Master professor at Centro Universitário Fag, Avenida das Torres, 500, 85806-095 Cascavel, PR, Brasil

\begin{abstract}
Resumo. O entendimento sobre a satisfação dos consumidores de vinho e as razões pelas quais bebem esta bebida, representa um desafio, pois não existem muitas pesquisas sobre esta temática. Diante deste contexto, foi realizada uma pesquisa de satisfação junto aos consumidores para observar quais os atributos relevantes e determinantes relativos às razões pelas quais bebem vinho. Foram entrevistados 300 consumidores entre 21 e 88 anos de idade, na cidade de Cascavel, no estado do Paraná. Notou-se que 57.67\% dos consumidores relataram como "importante" ou "muito importante" o fato do vinho contribuir para a prevenção de doenças cardíacas, e como atributo determinante no momento de escolha do vinho, independentemente do acompanhamento. Cerca de 55\% dos entrevistados consideraram como "importante" ou "muito importante", o fato de que o vinho é aromático e frutado. Em relação ao atributo indicativo de que o vinho é bom para esquecer os problemas, apenas $14.34 \%$ de consumidores o consideram "importante" ou "muito importante" no momento da escolha. Observou-se que a teoria de resposta ao item é uma importante ferramenta para avaliar o nível de satisfação dos consumidores de vinho.
\end{abstract}

\begin{abstract}
The understanding of the satisfaction of wine consumers and the reasons why it is consumed presents a challenge, since there is not much research on this subject. For this reason, a consumer satisfaction survey was carried out to observe the relevant and determinant attributes related to the reasons why they drink wine. A total of 300 consumers, between 21 and 88 years old, were interviewed in the city of Cascavel, in the state of Paraná. It was noted that $57.67 \%$ of consumers reported as "important" or "very important" the fact that wine contributes to the prevention of heart diseases, a determining attribute when choosing wine, regardless of the side dishes. About $55 \%$ of the interviewees considered the fact that the wine is aromatic and fruity as "important" or "very important". On the attribute indicating that wine is good to forget the problems, only $14.34 \%$ of consumers consider it "important" or "very important" at the time of the choice. The item response theory was observed to be an important tool to evaluate the level of satisfaction of wine consumers.
\end{abstract}

\section{Introduction}

The nutritional status of an individual depends on the balance of the nutrients ingested for the performance of their physiological functions in order to maintain the vitality of all the organs of the human body. Some conditioning factors for the degradation of the body, due to the physiological changes characteristic of aging, cause both physical and mental damage, and factors related to the socioeconomic and familial situation affect aging relatively by having influence with the diseases present in the emotional state of the individual [1,2].

Moderate wine consumption contributes to increased salivation and stomach activity in case of poor appetite, high potassium and low sodium content; it is excellent in diets for people with hypertension and increases enjoyment of meals for diabetics [3].

Moderate intake of 250 to $300 \mathrm{ml}$ per day has distinct benefits, especially associated with the causes of reduced mortality, reduction in the probability of type 2 diabetes, hypertension and the frequency of certain types of cancer, among several other diseases [3-5].

Research shows that small amounts of B vitamins (such as B1 (thiamine), B2 (riboflavin)) present in wine, with a small intake ranging from $90 \mathrm{ml}$ to $180 \mathrm{ml}$ before bedtime, help in relaxation mainly in people suffering from insomnia [6], as it induces sleep without causing restlessness or sleep apnea, preventing the use of tranquillizers and reducing the occurrence of Alzheimer's. That occurs because the polyphenols present in wine (mainly in red wine) would be responsible for avoiding the aging of the brain cells. It is observed that the diuretic characteristics of wine and the ingestion of water as its accompaniment reduce the risk of kidney stone development [7-9].

The department of health and social services warns that, for any type of treatment, the doctor should be asked about guidelines and medications used so that there is no harm to the health of the individual, since the drugs remain in the body for several hours 10 , and wine, which is not medicine, causes harm if consumed in excess. Alcohol, when consumed in excess, dehydrates and compromises brain and liver cells, which can cause alcoholism [11]. Therefore, one should observe the antecedent history of the person $[12,13]$ in order to have control over the amount ingested per day $[14,15]$; furthermore, it may cause behavioral disorders [16], and its continued and abusive consumption may cause cancer [17]. Alcohol 
metabolization depends on factors such as gender (as women are more vulnerable), body weight, the amount of enzymes to metabolize the substance and the concomitant use of food and medicines [18].

There is a need of studies on the behavior of beverages consumption, such as wine, for the understanding of the consumers' expectations in relation to health.

In this context, Item Response Theory (IRT) is a methodology that suggests ways of representing the relationship between the probability of an individual presenting a certain response to an item and its latent traits (capacities), by means of a mathematical model [19].

In the beginning of the last century, Thurstone's works $(1927,1928)$ provided a great contribution in the construction of latent trait measures, and especially in attitude measurement. In his work [20,21], he developed a method of statistical measurement called the Law of Comparative Judgment, which can be understood as the most important probabilistic precursor of the IRT [22]. In developing this method, Thurstone introduced two response mechanisms, or principles for constructing psychological scales, which are now known as cumulative and unfolding models [23].

Latent traits (or latent variables) are predicates of the individual that can not be directly observed, that is, there is no device capable of measuring them directly, such as a thermometer that directly measures temperature. Examples of latent traits are: level of satisfaction, knowledge, ability, degree of depression, etc. Therefore, these predicates are measured through secondary variables that are related to the trait studied. The latent trait is measured on a scale created through the application of IRT. This scale can be created with any mean and standard deviation values; however, it is common to use a scale $(0,1)$, that is, with mean zero and standard deviation equal to one.

There are many advantages in using the IRT instead of the Classical Test Theory (CTT), among which are: a) IRT allows comparisons of respondents from different populations when they are submitted to tests or questionnaires that have some common items, and also allows the comparison of individuals from the same population submitted to totally different tests. On the other hand, CTT allows only the possibility to compare individuals submitted to the same test [19]; b) In IRT, items and individuals are on the same scale; thus, the level of a characteristic that an individual possesses can be compared to the level of the characteristic required by the item, which facilitates the interpretation of the generated scale and allows also to know which items are producing information along the scale. On the other hand, in CTT, items and individuals are not on the same scale [24]; c) The IRT has the principle of invariance, that is, the parameters of the items do not depend on the latent trait of the respondent and the parameters of the individuals do not depend on the presented items, being this principle one of the great benefits of IRT. In CTT, the individual's score depends on the degree of difficulty of the items [25].

Although it was initially applied in the area of educational assessment [26], IRT has rapidly expanded to the most diverse areas that aim for evaluation, as in the case of satisfaction survey [27-29].

The IRT models depend on the type of item and the type of response process, which may be cumulative or non-cumulative. Cumulative models have emerged to fill deficiencies in classical theory, especially in educational assessment measures, which is why most published books and articles from IRT define these models by always taking as an example of latent traits the skill or proficiency. Thus, when considering this latent trait, what can be stated is that the cumulative IRT models are indicative of the probability of an individual providing or choosing a correct response to the item increase with the progress of their latent trait, that is, higher levels of latent trace lead to higher values of correct response probability, presenting a monotonic behavior in the Item Characteristic Curve (ICC) [30,31].

Non-cumulative models are the models for items with dichotomous response, or multiple choice items (corrected as right/wrong), of which the following stand out: the Oneparameter Logistic Model, the two-parameter Logistic Model, and the three-parameter Logistic Model [32].

In face of the aforementioned, this paper aims to use IRT to evaluate the level of satisfaction of adults and elderly individuals regarding wine consumption.

\section{Material and methods}

Adult and elderly consumers $(N=300)$ were interviewed in the age range of 21 to 88 years old, with an average of 54.5 years old, and 20 attributes were collected using the Likert scale. The questions refer to the decisions of the consumers when buying wine; however, 8 attributes had the standard error high and were initially grouped. With the grouping of values, reduction of the default error was not possible, so these attributes were ignored. The attributes ignored were: drinking wine moderately is healthy, white wine is not really wine, drinking wine is for alcoholics, wine causes acidity, I drink to be no different from friends, not being sure if it was the right choice when buying wine, wine is something that makes me indifferent, the doctor recommended. The attributes used in this work are: drinking wine gives positive feelings, wine is aromatic and fruity, wine helps to prevent heart disease, drinking wine is an act of sensuality, drinking wine relaxes, wine is a joyful drink, wine is good to warm, wine is good to forget the problems, I learned it from my parents, I learned from my friends, I enjoy buying wine, buying wine is like getting a gift.

The data were collected through a questionnaire in which the answers ranged from nothing important to very important, with a scale of 1 to 5 ( 1 - nothing important, 2 - not important, 3 - indifferent, 4 - important, 5 - very important ). The items described are shown in Table 1.

\subsection{Ethical procedures}

The ethical aspects of human research in Brazil are regulated by Resolution No. 466/12 of the National Health Council (CNS) in accordance with the Research Ethics Committees (CEP) and the National Commission of Ethics in Research (CONEP).

The present study was submitted to the Research Ethics Committee (CEP) on 09/24/2015 and approved on $10 / 8 / 2015$, under a consubstantiated opinion number 1.269.971.

\subsection{Statistical analysis of data}

The information collected from consumers was transformed into data to be analyzed to draw a profile of 
Table 1. Evaluated items on the reasons for drinking wine.

\begin{tabular}{|l|l|}
\hline Item & Description \\
\hline 1 & Drinking wine gives positive feelings \\
\hline 2 & Wine is aromatic and fruity \\
\hline 3 & Wine helps prevent heart disease \\
\hline 4 & Drinking wine is an act of sensuality \\
\hline 5 & Drinking wine relax \\
\hline 6 & Wine is a joyful drink \\
\hline 7 & Wine is good for heating \\
\hline 8 & Wine is good to forget the problems \\
\hline 9 & I learned from my parents \\
\hline 10 & I learned from my friends \\
\hline 11 & I'm happy to buy wine \\
\hline 12 & Buying wine is like getting a gift \\
\hline
\end{tabular}

Table 2. Distribuition of the absolute frequency of items.

\begin{tabular}{lccccc}
\hline Category & $\mathbf{1}$ & $\mathbf{2}$ & $\mathbf{3}$ & $\mathbf{4}$ & $\mathbf{5}$ \\
\hline Item 1 & 71 & 38 & 65 & 43 & 83 \\
Item 2 & 35 & 32 & 68 & 78 & 87 \\
Item 3 & 29 & 26 & 72 & 89 & 84 \\
Item 4 & 166 & 26 & 42 & 36 & 30 \\
Item 5 & 34 & 30 & 78 & 76 & 82 \\
Item 6 & 45 & 27 & 91 & 83 & 54 \\
Item 7 & 37 & 8 & 61 & 75 & 119 \\
Item 8 & 152 & 65 & 40 & 14 & 29 \\
Item 9 & 130 & 45 & 33 & 38 & 54 \\
Item 10 & 147 & 51 & 33 & 32 & 37 \\
Item 11 & 122 & 36 & 63 & 39 & 40 \\
Item 12 & 116 & 29 & 43 & 57 & 55 \\
\hline
\end{tabular}

consumers, facilitating and streamlining the understanding of this information transformed into data.

The data were tabulated and treated with a specific software, called MULTILOG, to estimate the parameters of the items and the latent trait. In the calibration process, the calibration parameters a of each item, the location parameters b of each category and each item, and the latent traits of the respondents were estimated according to the level of importance of each item.

\section{Results}

Table 1 presents absolut values of the valid answers for the 12 items used in the research on the reasons for drinking wine.

Table 2 presents relative values of the valid answers for the 12 items used in the research on the reasons for drinking wine. The items that are important to the consumer could be noticed, even if it is only a descriptive analysis and it is not possible to analyze the capacity to provide information regarding the quality of the items and the results obtained. In item 8 (wine is good to forget the problems), the amount of people who answered "not important" is 50.67. The question regarding item 7 (wine is good for heating), more than $64.67 \%$ (194 people) said to be "important" or "very important".

Figure 1 presents the graphs of ICC for the 12 items evaluated, with presentation from the left (nothing important) to the right (very important). When the item

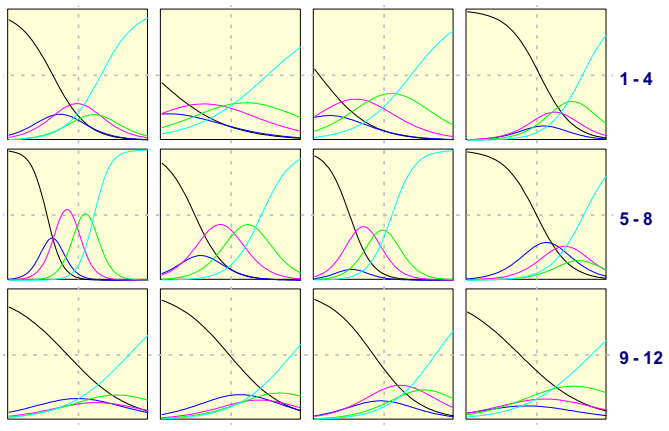

Figure 1. Graphs of Item Characteristic Curve.

Table 3. Distribuition of the relative frequency of items (in \%).

\begin{tabular}{lccccc}
\hline Categoria & $\mathbf{1}$ & $\mathbf{2}$ & $\mathbf{3}$ & $\mathbf{4}$ & $\mathbf{5}$ \\
\hline Item 1 & 23.67 & 12.67 & 21.67 & 14.33 & 27.67 \\
Item 2 & 11.67 & 10.67 & 22.67 & 26.00 & 29.00 \\
Item 3 & 9.67 & 8.67 & 24.00 & 29.67 & 28.00 \\
Item 4 & 55.33 & 8.67 & 14.00 & 12.00 & 10.00 \\
Item 5 & 11.33 & 10.00 & 26.00 & 25.33 & 27.33 \\
Item 6 & 15.00 & 9.00 & 30.33 & 27.67 & 18.00 \\
Item 7 & 12.33 & 2.67 & 20.33 & 25.00 & 39.67 \\
Item 8 & 50.67 & 21.67 & 13.33 & 4.67 & 9.67 \\
Item 9 & 43.33 & 15.00 & 11.00 & 12.67 & 18.00 \\
Item 10 & 49.00 & 17.00 & 11.00 & 10.67 & 12.33 \\
Item 11 & 40.67 & 12.00 & 21.00 & 13.00 & 13.33 \\
Item 12 & 38.67 & 9.67 & 14.33 & 19.00 & 18.33 \\
\hline
\end{tabular}

categories do not stand out in any region of the graph, it may be an indicator that the item does not have an acceptable quality to evaluate the latent trait or a problem in the sample is the determining factor for the graph not to express the expected effect. A low performance of graphs 9 to 12 can be seen. The items presented have a standard error below 1, and the one with the highest standard error is item $2(0.75)$, as shown in Table 4 . Item 5 presents the lowest standard error $(0,09)$.

Some items presented a standard error above 1, and then were grouped into three categories so that these categories could result in analysis with an acceptable standard error. However, these items did not present an acceptable reduction for the IRT analysis.

Table 3 contains the estimates of the item discrimination parameters, and the location of the categories with their standard errors is presented in parentheses, as well as the average value of the parameter $b$ for each item.

The first $b$, identified as b1, indicates the inflection point of the curve of the first category. The last $b$, identified as b4, indicates the inflection point of the last category curve. Intermediate b's refer to the midpoints of the peaks between the two adjacent categories [25]. There are two intermediate b's, identified as b2 and b3, where b2 is the mean between the points of peaks between categories 2 and 3, and b3 is the mean between the points of peaks between categories 3 and 4 .

The average of the values of $b$ indicates the position of the item in the scale created and also indicates the average level of satisfaction of the item.

One example is item 10 (I learned to drink wine from my friends), which has the highest average b value (1.25), 


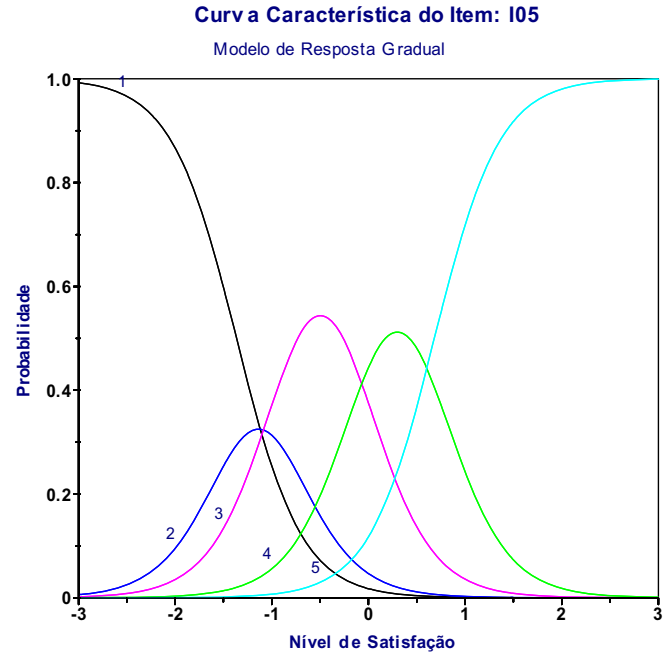

Figure 2. Item characteristic curve for item 5.

while item 2 (wine is aromatic and fruity) has the lowest value of $\mathrm{b}$ mean $(-1.04)$, with the overall mean being 0.16 . This is an indicator that the items are positioned between the values -1.04 and 1.25 in the scale, that is, with most of the average values of $b$ of the items are positive, the conclusion is that most of the items were evaluated as unsatisfactory, they require greater satisfaction to be agreed upon.

The degree of discrimination of an item (value of a) determines the quality of the item, that is, the larger the value of a, the greater the degree of discrimination of the item.

For a further interpretation of the Item Characteristic Curve (ICC), item 5 (drinking wine relaxes) was used with the values for $\mathrm{a}=2.95 ; \mathrm{b} 1=-1.37 ; \mathrm{b} 2=-0.91$; $\mathrm{b} 3=-0.08$; $\mathrm{b} 4=0.68$, the ICC being shown in Fig. 2 .

Figure 2 shows the ICC graph of item 5, according to the Graded Response Model (GRM) considering the satisfaction level between -3 and 3 , which is the interval in which practically all individuals will be located in the scale $(0.1)$.

Individuals with satisfaction on this scale, between approximately -3.0 and -1.1 , are more likely to respond to category 1 (not important); individuals with a satisfaction level between approximately -1.1 and -1.0 are more likely to respond to category 2 (little important); individuals with a satisfaction level between approximately -1.0 and 0.0 are more likely to respond to category 3 (indifferent); individuals with a satisfaction level between 0.0 and 0.7 are more likely to respond to category 4 (important), and individuals with a satisfaction level higher than 0.7 are more likely to respond to category 5 (very important). This is an example of an item that works properly to assess consumer satisfaction because it discriminates consumers among satisfaction categories.

\section{Discussion and conclusion}

The result of the IRT analysis presented a greater tendency for item 3 (wine contributes to prevent heart diseases), considering that it is "important" or "very important" for
$57.67 \%$ of respondents to this attribute as reasons for drinking wine, followed by $55.00 \%$ of those interviewed who considered wine to be aromatic and fruity as "important" or "very important". However, only $14.34 \%$ of respondents consider that wine is good for forgetting problems "important" or "very important" as a reason for drinking wine.

The consumption of red wine has been increasingly recognized by medicine. The components present in red wine are known as potent antioxidants and have been identified as having a range of biochemical and pharmacological effects, including anticarcinogenic, antiinflammatory and antimicrobial properties. It is important to note that these benefits only occur when wine is moderately consumed, up to two glasses per day, as part of a balanced diet and mainly by people who do not have a contraindication to the consumption of alcoholic beverages. Moderate wine intake may be beneficial as long as it is moderately consumed. The alcohol found in any drink dehydrates and compromises brain cells, liver cells, and can cause alcoholism. It can cause behavioral disorders, and its abusive and continued consumption induces cancer [33].

As mentioned in other studies on wine consumers, there is an understanding that this drink, if consumed in limited quantities, may have beneficial effects on health, and consumers believe that it is a healthy alternative when compared to other alcoholic beverages [34-36].

Studies have shown that low to moderate wine consumption is associated with reduced health risk and that abusive use of alcohol can increase this risk. Wine, as an alcoholic beverage, can meet consumer demand to provide all the expected benefits. In contrast to their ethanol content, many wines contain significant concentrations of polyphenolic antioxidants, which have an impact on the health and well-being of individuals [37]. Resveratrol is a polyphenol that can be found primarily in grape seeds, black grapes and red wine, being a powerful antioxidant and improving circulation $[38,39]$. This fact may be associated with the opinion of consumers who consider the prevention of heart diseases due to wine ingestion to be "important" or "very important" [40].

Esters constitute the second major volatile component present in wine and have long been considered as contributors of wine aroma, as the fruity attribute [41]. In South Australia, the removal of leaves has been reported to exert beneficial effect on the aroma of wine, increasing the intensity of the fruity attribute [42].

The aroma is the perception of the volatile components of the food in the mouth, which are perceived in the posterior nostrils of the nasopharynx, during respiratory exhalation or after swallowing [43].

For $14.34 \%$ of the interviewees, alcohol use is associated with the forgetting of problems, which indicates that they possibly use this justification for consumption of wine. In other studies involving adolescents, the consumption of alcoholic beverages is noted to be associated with the purposes like the fun, the company of the friends and the flight from reality. Expectations regarding the effects of alcohol have important influences on the onset and maintenance of alcohol use and the emission of behaviors related to alcohol use $[44,45]$. 
Unemployment, lack of family support and marital disagreements are the main reasons why individuals start drinking alcohol to forget such problems. It is believed that the fragility of social bonds originates mainly in the precarious social circumstances in which these bonds are formed and maintained [46].

\section{Conclusion}

IRT presented itself as an adequate tool to measure the level of satisfaction of wine consumers, by ordering items according to this classification, and revealed the need to include items that require a higher level of acceptance, such as an item "hard" to improve the estimate of satisfied consumers. The association of wine consumption with prevention of heart diseases could be observed to be above the sensory aspect (fruity aroma) and also the behavior of flight from reality (drinking to forget the problems), denoting that there is a concern of the consumers with their health as well.

\section{References}

[1] L. Campos, Obtenção de extratos de bagaço de uva Cabernet Sauvingnon (Vitis vinifera): parâmetros de processo e modelagem matemática (Tese). (Florianópolis: Universidade Federal de Santa Catarina, 2005)

[2] A.P.R.C. Ornelas, Rev. Nutr. 13, 157 (2000)

[3] M.O. Jackson, Social and Economic Networks (Princeton University Press, 2008), ISBN 9780691148205

[4] Q. Chen, S. Ganapathy, K.P. Singh, S. Shankar, R.K. Srivastava, PLoS One (2010), DOI: http://dx. doi.org/10.1371/journal.pone.0015288

[5] M. Cemek, F. Yilmaz, M.E. Buyukokuroglu, A. Buyukben, F. Aymelek, A. Ayaz, J. Med. Food 15, 747 (2012)

[6] R. Kastenbaum, in Proceedings of the Wine, Health and Society. A Symposium (1982), p. 87

[7] A.K.M. Prado, M.H. Caetano, R. Benedetti, P.C.D. Benedetti, Rev Científica Unilago, Os Efeitos do Consumo de Vinho na Saúde Humana, 2013

[8] B.J. Ector, J.B. Magee, C.P. Hegwood, M.J. Coign, Am. J. Enol. Vitic. 47, 57 (1996)

[9] A.L. Faller, E. Fialho, J. Food Compos. Anal. 23, 561 (2010)

[10] Nihseniorhealth, Alcohol Use and Older Adults, 2015, Disponivél em <http://nihsenior health.gov/alcoholuse/alcoholandaging/ $01 . \mathrm{html} />$

[11] N. Mota, R. Álvarez-Gil, M. Corral, et al., Gac. Sanit 24, 372 (2010)

[12] J. Pons, S. Buelga, Interv. Psicosoc 20, 75 (2011)

[13] N. Obradors-Rial, C. Ariza, C. Muntaner, Gac. Sanit 28, 381 (2014)

[14] E.A.P. Poelen, R.H.J. Scholte, G. Willemsen, D.I. Boomsma, R.C.M.E. Engels, Drinking by parents, siblings, and friends as predictors of regular alcohol use in adolescents and young adults: a longitudinal twin-family study (Oxford University Press, 2007), vol. 42 , p. 362
[15] S. Goodman, Int. J. Ine Business Res. 21, 41 (2009)

[16] A. Hertzberg, G. Malorgio, Wine demand in Italy, an analysis of consumer preferences (New Medit, 4/2008, 2008), p. 40

[17] J. Madeira, F. Duarte, M.M. Barreira, 2009 Wine purchase and consumption behaviour of young adults in Portugal: Is age a differentiation factor? (Universidade Técnica de Lisboa, 2010), p. 63

[18] A.I. Balsa, J.F. Homer, M.F. Fleming, M.T. French, Gerontologist 48, 622 (2007)

[19] D.F. Andrade, H.R. Tavares, R.C. Valle, Teoria da Resposta ao Item: conceitos e aplicações (São Paulo, Associação Brasileira de Estatística, 2000)

[20] L.L. Thurstone, Psychol. Rev., 273 (1927)

[21] L.L. Thurstone, Am. J. Sociol. 33, 529 (1928)

[22] B.W. Junker, K. Sijtsma, Behaviormetrika, 33, 75 (2006)

[23] D. Andrich, Appl. Psychol. Meas., 33 (1988)

[24] S. Embretson, S.P. Reise, Item Response Theory for Psychologists (Lawrence Erlbaum Associates, New Jersey, 2000)

[25] R.K. Hambleton, H. Swaminathan, H.J. Rogers, Fundamentals of Item Response Theory (Newbury Park, CA, Sage, 1991)

[26] T.F. Soares, Pesqui Oper. 25, 83 (2005)

[27] S.L.V. Bortolotti, Aplicação de um modelo de desdobramento graduado generalizado da teoria da resposta ao item - TRI (Dissertação) (Florianópolis: Universidade Federal de Santa Catarina, 2003)

[28] S.L.V. Bortolotti, D.F. Andrade, Aplicação de um modelo de desdobramento graduado generalizado GGUM da teoria da resposta ao item. E A E, São Paulo 18, 157 (2007)

[29] F.J. Costa, Mensuração e desenvolvimento de escalas, aplicações em administração (Ciência Moderna, Rio de Janeiro, 2001)

[30] E.A.C. Araujo, D.F. Andrade, S.L.V. Bortolotti, Rev. Esc. Enferm. USP (2009)

[31] E.J. Dezengrini, S.L.V. Bortolotti, S.N.T.G. Mendonça, Tecnologia no Controle de Produção (Curitiba: Appris, 2018)

[32] M.E. Bernard, J. Ration Emot. Cogn. Behav/ Ther. 16, 183 (1998)

[33] C. Carvalho, Anuário Brasileiro de Uva (Editora Gazeta, Santa Cruz do Sul, 2016)

[34] L.M. Higgins, E. Llanos, Wine Econ Policy 4, 3 (2015)

[35] C.A. Wright, C.M. Bruhn, H. Heymann, C.W. Bamforth, J. Food Sci. 73, 8 (2008)

[36] Y.J. Yoo, A.J. Saliba, J.B. Macdonald, P.D. Prenzler, D. Ryan, Food Qual. Prefer. 2, 531 (2013)

[37] D.M. Goldberg, J. George, G. Soleas, J. M. Biochem. 2, 93 (2011)

[38] A.S. St. Leger, A.L. Cochrane, F. Moore, Lancet 1, 1017 (1979)

[39] C. Stockley, P.L. Teissedre, M. Boban, C. Di Lorenzo, P. Restani, Food Funct. 3, 995 (2012)

[40] L. Brown, P.A. Kroon, D.K. Das, et al., Alcohol Clin. Exp. Res. 33, 1513 (2009)

[41] K.M. Sumby, P.R. Grbin, V. Jiranek, Food Chem. 121, 1 (2010) DOI: http://dx.doi.org/10. 1016/j.foodchem.2009.12.004 
[42] J. Marais, J.J. Hunter, P.D. Haasbroek, South African J. Enol. Vitic. 20, 19 (1999)

[43] S.D. Dutcosky, Análise sensorial de alimentos $4^{\mathrm{a}}$ ed. (Curitiba: Champagnt, 2013)

[44] A. Fachini, F.F. Erikson, Arch. Clin. Psychiatry. 2, 68 (2012)

[45] R.A. Martins, G.V. Parreira, L.A.N. Cruz, I.A. Silva, Expectativas sobre os efeitos do uso de álcool e padrão de beber em alunos de ensino médio. SMAD, Revista eletrônica saúde mental álcool e drogas. 2010 1, 1 (2010). Disponível: http://pepsic. bvsalud.org/scielo.php?script $=$ sci arttext\&pid $=$ S1806-69762010000100009

[46] C.N. Nascimento, J.S. Justo, Psicol. Reflex Crít 13, 529 (2000) 